\title{
Strengthening Sustainable Northern Food Systems: Federal Policy Constraints and Potential Opportunities
}

\author{
Amanda Wilson, ${ }^{1}$ Charles Z. Levkoe, ${ }^{2}$ Peter Andrée, ${ }^{3}$ Kelly Skinner, ${ }^{4}$ Andrew Spring, ${ }^{5}$ \\ Sonia Wesche ${ }^{6}$ and Tracey Galloway ${ }^{7}$
}

(Received 6 November 2019; accepted in revised form 11 May 2020)

\begin{abstract}
This paper explores how Canadian federal policy and frameworks can better support community-based initiatives to reduce food insecurity and build sustainable food systems in the North. Through an examination of the current state of food systems infrastructure, transportation, harvest, and production in the Yukon, Northwest Territories, Nunavut, Nunavik, and Nunatsiavut, we argue in favour of a multi-sector approach that supports diversified food systems, including traditional/country food production and distribution, in a way that values and prioritizes community-led initiatives and Indigenous peoples' self-determination and self-governance. The challenge of developing sustainable, northern food systems requires made-in-the-North solutions that are attuned to cultural, geographic, environmental, and political contexts. Recent policy developments suggest some progress in this direction, however much more work is needed. Ultimately, sustainable northern food systems must be defined by and for Northerners at community, local, and regional levels, with particular attention paid to treaty rights and the right to self-determination of First Nations and other Indigenous communities.
\end{abstract}

Key words: food system; food policy; North; Indigenous; Arctic; sustainable; food security; food sovereignty

RÉSUMÉ. Cet article se penche sur la manière dont les politiques et les cadres de référence fédéraux du Canada peuvent mieux soutenir les initiatives communautaires afin d'atténuer l'insécurité alimentaire et d'édifier des systèmes alimentaires durables dans le Nord. En nous appuyant sur l'examen de l'état actuel de l'infrastructure des systèmes alimentaires, du transport, des récoltes et de la production du Yukon, des Territoires du Nord-Ouest, du Nunavut, du Nunavik et du Nunatsiavut, nous plaidons en faveur d'une approche multisectorielle favorisant des systèmes alimentaires diversifiés, y compris la production et la distribution d'aliments traditionnels ou du terroir, valorisant et priorisant les initiatives communautaires de même que l'autodétermination et l'autonomie gouvernementale des peuples autochtones. Le défi consistant à concevoir des systèmes alimentaires durables dans le Nord nécessite des solutions provenant du Nord, solutions qui tiennent compte des contextes culturel, géographique, environnemental et politique. De récents développements en matière de politiques suggèrent un certain progrès, mais il reste toutefois fort à faire dans ce sens. Au bout du compte, les systèmes alimentaires durables dans le Nord doivent être définis par et pour les gens du Nord à l'échelle communautaire, locale et régionale, en accordant une attention particulière aux droits issus des traités ainsi qu'au droit à l'autodétermination des Premières Nations et d'autres collectivités autochtones.

Mots clés : système alimentaire; politique alimentaire; Nord; autochtone; Arctique; durable; sécurité alimentaire; souveraineté alimentaire

Traduit pour la revue Arctic par Nicole Giguère.

\section{INTRODUCTION}

Scholars have documented that high levels of food insecurity in northern Canadian communities result from a complex set of environmental, socioeconomic, logistical, and political challenges (Power, 2008; Egeland, 2010; Socha et al., 2012; CCA, 2014). While reports and media attention have begun to galvanize public interest and political will, there is not yet a coordinated strategy to advance substantive policy and program solutions to address these

\footnotetext{
${ }^{1}$ School of Social Innovation, Saint Paul University, 223 Main Street, Ottawa, Ontario K1S 1C4, Canada; awilson@ustpaul.ca

2 Department of Health Sciences, Lakehead University, 955 Oliver Road, Thunder Bay, Ontario P7B 5E1, Canada

${ }^{3}$ Department of Political Science, Carleton University, 1125 Colonel By Drive, Ottawa, Ontario K1S 5B6, Canada

${ }^{4}$ School of Public Health and Health Systems, University of Waterloo, 200 University Avenue West, Waterloo, Ontario N2L 3G1, Canada

${ }^{5}$ Laurier Centre for Sustainable Food Systems, Wilfrid Laurier University, 75 University Avenue West, Waterloo, Ontario N2L 3C5, Canada

${ }^{6}$ Department of Geography, Environment and Geomatics, University of Ottawa, Ottawa, Ontario K1N 6N5, Canada

${ }^{7}$ Department of Anthropology, University of Toronto Mississauga, 3359 Mississauga Road, Mississauga, Ontario L5L 1C6, Canada

(c) The Arctic Institute of North America
} 
widespread and interrelated issues. For the purposes of this research, the North is defined as encompassing Yukon, Northwest Territories, Nunavut, Nunavik, and Nunatsiavut (Fig. 1). The authors recognize that the North can also be defined to include the northern regions of provinces, many of which experience similar challenges to those identified in this paper. Local and regional efforts led by communities themselves are underway to build more sustainable food systems across the North. However, the governance landscape, which includes policies and programs established at First Nation, municipal, regional, territorial, provincial, and federal levels, imposes constraints on these community-based efforts.

In recent years, relevant policy frameworks have emerged that contain measures to strengthen food systems, including Nutrition North Canada (NNC, 2017), the Canadian Agricultural Partnership (AAFC, 2018a), the revised Fisheries Act (DFO, 2019), and the recently announced (June 2019) Food Policy for Canada (YAPC and AICBR, 2017). Our specific focus in this paper is on how federal policy and frameworks can better support community-based initiatives to reduce food insecurity and build sustainable food systems in the North. In general terms, sustainable food systems are herein defined as food systems - whether based on wild harvesting or agricultural production - that can meet the needs of current populations without jeopardizing the ability of future generations to meet their needs (WCED, 1987). Community-based initiatives are those that aim to increase access to more sustainably harvested, produced, processed, or distributed foods created by and for northern communities, usually led by Indigenous governments, local governments, small businesses, or regional nonprofit organizations based in the North. Such initiatives may take place at the local scale (e.g., within one specific community) or at a more regional scale (e.g., at the scale of a land-claim area or portion thereof, involving multiple communities with shared characteristics). Recognizing the diversity that exists across Canada's northern regions, this paper is grounded in an examination of the current state of food systems infrastructure, transportation, harvest and production in Yukon, Northwest Territories, Nunavut, Nunavik, and Nunatsiavut. Our recommendations draw on research conducted by an interdisciplinary team of scholars in partnership with several northern-based community organizations.

\section{Identifying Key Policy Recommendations}

Overall, we argue that sustainable northern food systems depend on healthy environments and healthy people, and that these relationships are reciprocal. This means, for example, that efforts toward the scaling-up of harvesting include monitoring of wildlife populations and social and ecological health. It also means that the provision of food cannot be defined solely by market forces, as market-based initiatives are notoriously ineffective at supporting ecosystem health. Further, locally controlled subsistence supply chains, cooperatives, and alternative forms of food distribution require space and support to flourish. For example, these systems can usefully be buttressed by essential services to ensure that when market competition fails, Northerners do not bear a disproportionate cost burden.

Overall, we suggest a multi-sector approach that supports diversified food systems, including harvesting, agricultural production, fisheries, food processing and distribution, and retail, in ways that value and prioritize Indigenous peoples' self-determination and self-governance. Our proposals are founded upon a belief that Indigenous food sovereignty must underpin efforts to strengthen vibrant, resilient, and sustainable food systems in the North. As a result, whatever policies are deployed, northern Indigenous peoples must ultimately hold decision-making power that includes jurisdiction over the resources that will ensure program efficacy over the medium- and long-term.

While food security is the most common term associated with food system issues in the North, the broader context that influences food accessibility and availability suggests "food sovereignty" as a more holistic and appropriate concept grounded in self-determination and Indigenous rights. Within the context of Indigenous food systems, the concept of food sovereignty acknowledges the historical and continued influence of colonialism on Indigenous food systems and the inherent rights and responsibilities of Indigenous peoples. These include, but are not limited to, the protection of the air, lands, and waters for future generations. Food sovereignty, as a principle that embodies greater emphasis on Indigenous-led and Indigenousderived solutions to food insecurity, offers a promising conceptualization for sustainable northern food systems.

Strengthening sustainable food systems is not just a technical exercise. Following Rodon and Schott (2014), we recognize that defining what sustainable food systems do and can look like in the North involves environmental, social, cultural, financial, and physical infrastructure considerations. For example, the role of market transactions in the distribution of traditional/country food is as much cultural and political as it is an economic issue. In some communities, the sale of traditional/country foods is seen as an important step in building a more sustainable food system, while in others such sales go against cultural norms and may even be prohibited by treaty and landclaim agreements. Because of how northern food systems have changed over the last century, we also recognize that imported foods play an important (and still growing) role in northern diets. As a result, community-based initiatives to ensure equitable access to healthy, minimally processed imports from the south are critical while more sustainable regional harvesting, production, and distribution systems remain underdeveloped. Finally, we take as given that sustainable northern food systems must ultimately be defined by and for Northerners at community, local, and regional levels, with particular attention paid to treaty 


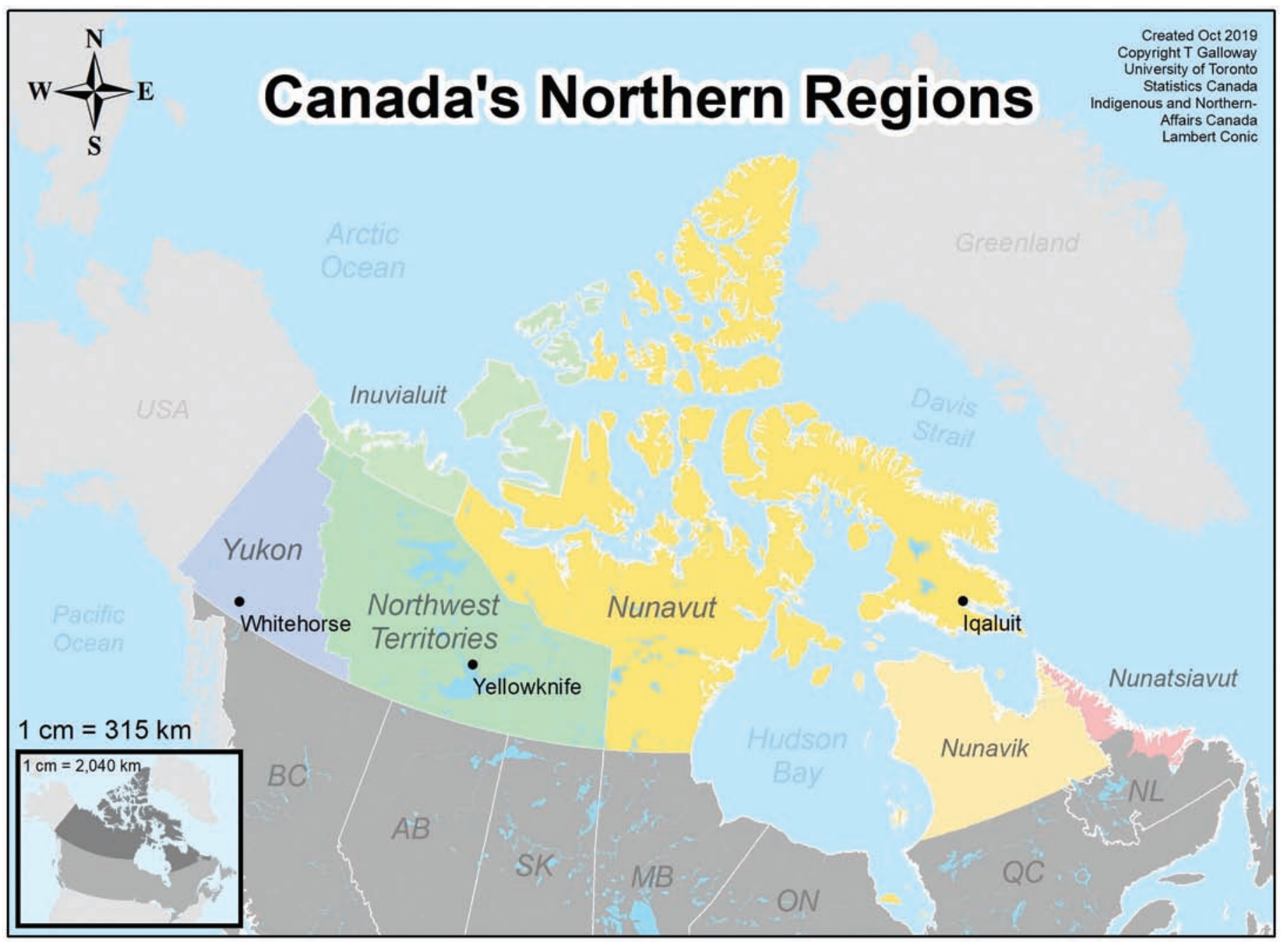

FIG. 1. Map of the northern regions included in the scope of this study: Yukon, Inuvialuit, Northwest Territories, Nunavut, Nunavik, and Nunatsiavut.

rights and the right to self-determination of Indigenous nations and communities (Jorgensen, 2007).

The present study uses a mixed-methods approach to explore the current state of northern food systems, identifying both the challenges preventing development of sustainable initiatives and the complex governance landscape within which northern food systems exist. Building on our collective research, we provide a series of policy and program recommendations that address barriers and offer more effective approaches to supporting sustainable and resilient food systems in northern Canada.

\section{METHODS}

To explore the role of federal policy measures in relation to sustainable northern food system initiatives, our research approach combined a literature review, asset mapping, and community engagement. The three methods were used concurrently, enabling the opportunity for questions and gaps identified to be explored across multiple data-gathering efforts. The literature review explored peer-reviewed, government and non-governmental literature published from 2000 to the present using the search terms "northern/ Arctic," "food security," "food sovereignty," "Indigenous," "Inuit," "First Nation," "Métis," "harvest," and "fishing" within online databases. Reference lists from the resulting articles were reviewed, which revealed additional articles relevant to the inquiry. Key community organizations also provided access to reports not available online. In total, 233 papers were identified as relevant to the inquiry. These were analyzed by teams of authors with subject-matter expertise in the relevant domains and using an analytic approach co-developed by authors with input from agency and community partners (see supplementary Appendix for further details). The literature review for this project is the subject of a separate publication currently being prepared.

We used online mapping to identify assets related to food production and harvest, transportation and distribution, food processing, as well as key social and community-level supports, and networks for knowledge sharing, capacity building, and food system coordination. The purpose was to highlight existing capacities that could be replicated and scaled, as well as notable gaps in need 
of targeted support. Asset mapping was accomplished through an environmental scan of relevant websites, directories, and existing food systems inventories (e.g., the Arctic Institute of Community-Based Research's Healthy Living Inventory [AICBR, 2017b], Inuit Tapiriit Kanatami's [2020] Nuluaq Community-based Food Initiatives Mapping Project, and Food Secure Canada's [FSC, 2011a] Northern and Remote Local Connections Mapping Project). Researchers and project partners contributed to this mapping exercise by identifying additional assets known to them through their networks.

Three community engagement sessions (two conducted in person-one in Yellowknife and another in Whitehorse - and one conducted virtually) were held to enrich the literature review and asset mapping, solicit expert community knowledge, deepen the analysis, highlight necessary revisions or reformulations, and identify points of tension and consensus. Participants were identified using convenience sampling through the researchers' existing networks and included harvesters, fishers, farmers, gardeners, and staff of governmental and non-governmental organizations. During each of the three engagement sessions, 7-15 participants were provided with an overview of study objectives, preliminary findings, and draft policy recommendations. We then posed a series of open-ended questions intended to generate dialogue and feedback, as well as new information about local and regional food systems. Representatives from partnering community organizations facilitated these meetings and took notes, which were shared with the wider research team. Community partners organized their engagement session according to what worked best for their region and context; thus, each session looked different in terms of structure and format. Some participants also submitted written feedback via email following the engagement sessions. This information was then incorporated into the study results. Knowledge synthesis occurred through a series of discussions and draft documents, as authors refined and revised results using consensus decision-making to produce a final series of observations and policy recommendations.

\section{Study Limitations}

Our study has a number of limitations worthy of note. The first is the impossibility of a broad policy review to encompass the diversity of issues and perspectives that pertain across Canada's vast northern regions. While we have endeavored to be inclusive with respective to northern and Indigenous populations, that effort has synthesized many distinct and important community concerns that require immediate policy action. Similarly, while the community engagement sessions included many Indigenous individuals, they should not be perceived as comprehensive engagements with Indigenous people or communities on these issues, which were limited in this study both by our broad, national approach and by constraints on time and resources. For example, given the location of two of the sessions (Whitehorse and Yellowknife), and the use of Internet for the third, there was an overrepresentation of urban vs. remote, western vs. central/eastern, and First Nation/Métis vs. Inuit community perspectives in this portion of the data. We have endeavored to mitigate these concerns by seeking broad representation in the partnerships and literature that informed this paper and by advancing policy recommendations that offer significant potential for food system improvement within and across regional divides.

\section{CURRENT STATUS OF NORTHERN FOOD SYSTEMS}

Recent decades have brought economic, environmental, and social changes to the North, which have deeply impacted people's access to and relationships with food (Kuhnlein et al., 2004; Power, 2008; Sharma, 2010; Martin, 2012; CCA, 2014). Northern food systems comprise "traditional/country" foods (e.g., wild game, birds, eggs, fish, and marine mammals) and seasonal wild berries and plants, locally grown foods (e.g., vegetables), as well as imported fresh and processed foods. While generally treated distinctly in discussions of northern food systems, in this paper we provide an overall picture of these foodprovisioning activities and relationships, as well as their connection to processing, distribution, and consumption activities. We use traditional/country foods to refer to foods that form a significant part of the diet of northern Indigenous people, both past and present, and include foods harvested, gathered, fished, or hunted from the lands, waters, and skies for subsistence or sharing. "Traditional food" is the term more commonly used in First Nations and Métis communities, while "country food" is the preferred term in the Inuit context (CCA, 2014).

Recent research highlights the inflated costs of storebought foods and the disproportionate prevalence of moderate and severe household food insecurity (Egeland et al., 2011; Ford and Beaumier, 2011; Huet et al., 2012; PROOF, 2018; Fafard-St. Germain et al., 2019). Food prices in the North remain extremely high (Veeraraghavan et al., 2016; Hammond, 2017). For instance, the weekly cost for a nutritious food basket is \$230.96 in Edmonton and \$232.96 in Montreal, but \$531.28 in Old Crow, Yukon (NNC, 2018). In some Nunavut communities, a nutritious food basket costs \$23000 annually, outpacing annual social assistance rates for a family of four (Nunavut Bureau of Statistics, 2018). Accordingly, the 2007-08 Inuit Health Survey documented some of the highest food insecurity rates to date (Egeland, 2010; Egeland et al., 2010).

High food costs are only one aspect of food provisioning in the North. Food security has been shown to improve when residents have access to culturally appropriate, regional food, which reinforces the importance of supporting subsistence food systems and traditional economies (Power, 2008; Slater and Yeudall, 2015; Dachner and Tarasuk, 2016). Maintaining traditional/country food harvesting 
practices is of critical importance to communities, but increasingly so is developing local production of produce and meats and better access to affordable store-bought foods. These three elements working together can have a meaningful impact on food security and overall quality of life within northern communities.

The interplay between the above-mentioned elements illustrates the utility of a food systems perspective, which considers the interdependent webs of social, cultural, economic, political and ecological activities, actors and relationships. Beyond simply identifying the various points along a food chain, it focuses on interrelationships between the different elements, which create a complex whole that is greater than the sum of its parts (Tansey and Worsley, 1995; Ericksen, 2008; Spring et al., 2018):

For Northern Indigenous Peoples, food security is more than just having a full stomach; food is linked to identity, culture and way of life. Food is central to the physical, emotional, spiritual, and mental health of Indigenous Peoples. It is an issue tied closely with survival and rights of self-determination.

(Butler Walker et al., 2017)

A food systems perspective not only makes visible the current constellation of food-provisioning activities and the various internal and external factors that shape it, but also highlights opportunities to shift food systems towards greater social, environmental, and economic sustainability. In doing so, this approach prompts a discussion not just of what is, but also a visioning of what could be.

Two aspects in particular merit consideration across the various food-provisioning activities and relationships discussed here. The first is that any discussion of northern food systems must contend with the profound impact of climate change on northern ecosystems. Parts of northern Canada have seen an increase in temperature roughly four to five times greater than the global average over the past decade (IPCC, 2014). Permafrost thaw, degrading sea ice, changing migratory patterns, increased intensity and frequency of wildfires, and changes in water availability are among the range of impacts affecting northern communities (Price et al., 2013; IPCC, 2014). These impacts have direct and often negative consequences on access to traditional/ country foods, including decreases in populations of food species, increases in populations of predatory species, and the introduction of new species (Ford et al., 2006; Guyot et al., 2006; Nickels et al., 2006; Andrachuk and Smit, 2012; Wakegijig et al., 2013; IPCC, 2014).

Second is the historical and on-going manifestation of colonialism, including residential and day schools, forced resettlement, and continued discrimination and oppression against Indigenous peoples in Canada today. Attempts to strengthen and build sustainable food systems in the North cannot be disarticulated from these deeper structural issues. Instead, support for northern food systems should be seen as a way to increase Indigenous self-determination and move toward reconciliation. Specifically, in the context of food policy discussions, it is important to acknowledge that the nature and inherent logic of Indigenous and Western governance approaches differ significantly (Fondahl and Irlbacher-Fox, 2009).

We identified key groupings of barriers within various food system sectors that pose significant challenges to the scaling-up of regional sustainable food system initiatives in the North and to improving provision of affordable, healthy, minimally processed, store-bought foods from the south (Fig. 2). An explanation of the current status of food systems is organized around these groupings.

\section{Harvesting}

Traditional/country foods remain a strong pillar of northern food systems in Canada, and Indigenous people remain strongly connected to the land through their foodways. At the same time, some studies document declines in harvesting activities (Nancarrow and Chan, 2010; Rosol et al., 2016), which suggests this connection is constrained by a number of factors. The high cost of living in the North (Pakseresht et al., 2014; SC, 2017) necessitates participation in the market economy, leaving many people less time to participate in traditional harvest activities. Time is not the only factor; one of the principal barriers to harvest activity is the high cost of the equipment (Chabot, 2003; Chan et al., 2006; Ford et al., 2006; Lambden et al., 2006; Power, 2008; Pal et al., 2013). For example, a survey of Indigenous women from 44 Arctic communities found that up to $50 \%$ of participants had inadequate access to fishing and hunting equipment and supplies, and up to $46 \%$ indicated that fishing and hunting were unaffordable (Lambden et al., 2006). This lack of access to both the necessary equipment and financial resources creates a catch-22 cycle where financial resources are required to purchase and maintain fishing or hunting equipment, yet participation in the formal economy denies individuals the time and flexibility needed to engage safely in traditional/ country food harvesting (Shirley, 2016). Gombay (2009:122) sums up the central challenge facing many harvesters in the North: "The challenge has become how to find the money and time to be able to go and harvest food, and to do so in a way that enables people to continue to share it." Most concerning is the fact that some youth are not participating in traditional practices and therefore lack the skills needed to survive on the land (Power, 2008; Pearce et al., 2011). This decline of harvesters over the long term translates to increased food insecurity and further weakening of food-sharing networks (Beaumier and Ford, 2010; Collings et al., 2016).

Climate change is also a barrier, limiting the availability of traditional/country foods and impacting community health. As many communities depend on traditional/ country food for their dietary needs, climate-mediated impacts have significant implications for multiple aspects of community health (Ford et al., 2006; Cunsolo-Willox et al., 


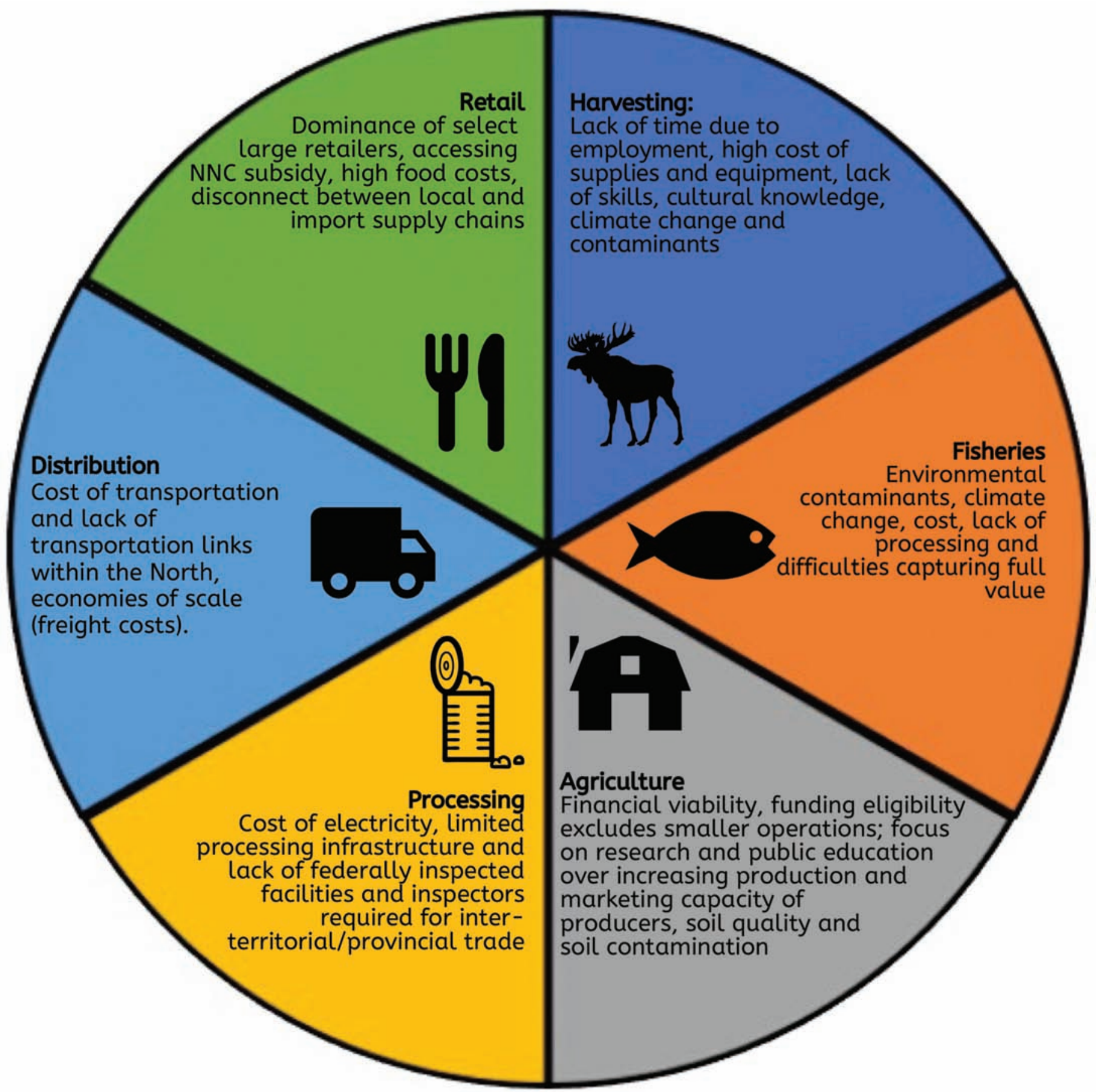

FIG. 2. A summary of key barriers and challenges identified for each of the six food systems focus areas: harvesting, fisheries, agriculture, processing, distribution, and retail.

2012). There are reports of declining populations and health status of many commonly hunted and harvested species (Furgal and Rochette, 2007; Environment Yukon, 2010; Eneas, 2018; Parlee et al., 2018). For example, in a survey of First Nations, Dene/Métis and Inuit women, between $10 \%$ and $38 \%$ of participants reported recent changes either in the quality or health of country food species, including physical changes in the animals as well as decreasing availability (Lambden et al., 2007). Contamination of traditional/country food species is also a major concern for northern communities (Kuhnlein and Chan, 2000; Donaldson et al., 2010, Letcher et al., 2010).

The environments that sustain traditional/country food sources also come under threat from other economic activities. For example, a study of barren-ground caribou in the Northwest Territories documented the impact of habitat disturbance from mineral resource development (Parlee et al., 2018). Over 30 million hectares of land were disturbed as a result of mineral staking, exploration, construction, and project development, with both Inuvialuit and Gwich'in 
harvesters in the area reporting significant reductions in caribou harvests associated with habitat disturbance. As harvests decline, communities become increasingly dependent on store-bought foods imported from the south. Access to these foods is constrained by high prices resulting from the communities' remote locations, distance from distribution centres, comparatively small populations, and dependence on relatively low-wage, seasonal employment. Increased reliance on store-bought foods contributes to increased prevalence of chronic diseases (e.g., cardiovascular disease, diabetes, and cancer) among northern Indigenous populations whose health needs are already inhibited by limited access to health services (Circumpolar Inuit Cancer Review Working Group et al., 2008; Damman et al., 2008).

\section{Agriculture}

Despite challenging growing conditions, there is a small but vibrant agricultural sector in parts of the North, which includes the production of various meat animals, eggs, grains, vegetables, fruit, nuts, and hay (Statistics Canada, 2016). Commercial-scale agriculture is limited to the Yukon and Northwest Territories, however, community garden and greenhouse projects exist across all five regions under study, as does a growing interest in the potential for new agricultural ventures such as hydroponic vegetable production (Robinson, 2010; GY, 2016; Chen and Natcher, 2019).

Agriculture in the North requires a modified conceptualization of commercial scale. The distinctions between commercial, community, and subsistence production are much more fluid than in other parts of Canada. Following a community engagement session on the federal government's Food Policy for Canada, a joint report by the Yukon Anti-Poverty Coalition (YAPC) and the Arctic Institute of Community-Based Research (AICBR) highlighted the distinctiveness of northern agriculture:

There is a growing local food movement in Yukon and there was a strong sense that strengthening our local food system is a priority. The agricultural context in the Yukon and across the North differs quite starkly with South of $60^{\circ}$. Yukon farmers are mostly focused on local markets ...

(YAPC and AICBR, 2017:6)

The financial viability of northern farms is currently dependent on government support. A 2015 study of Yukon agriculture found that $40 \%$ of the 45 farmers who completed the survey reported a net loss in 2012, and $87 \%$ generated a net income of less than $\$ 20000$ (GY, 2016). Perhaps more illustrative is the fact that $62 \%$ of Yukon farmers had a gross income of under $\$ 20000$, meaning that farm revenues are still, on average, quite small (Institute for Sustainable Food Systems, 2015). Access to suitable agricultural land is also a challenge in many parts of the North, as is poor soil quality, exacerbated at some sites by soil and groundwater contamination from mining (Reyes et al., 2015).

Small markets and lack of capacity are also constraints. One engagement session participant from Northwest Territories observed: "this is why small-scale growers haven't been able to grow their businesses because there is virtually no way to sell their produce other than through the farmer's market." Lack of local processing infrastructure makes it difficult for producers to meet food safety certifications and other regulatory requirements. Other challenges include regular, affordable access to animal feed, fertilizer, and other agricultural supplies, as well as cold-storage infrastructure at community or commercial scales. A participant from the Yukon engagement session described the limited storage and inputs (such as animal feed and fertilizer) as "choke points" for the local food system. Similarly, a northern farmer's market representative identified the lack of cold storage as a key reason that the market had been unable to expand.

A small but growing literature focuses on the potential for new growing technologies to address food security in the North, including heated greenhouses and hydroponic systems (Day and Landolt, 1978; Avard, 2015; Brown-Paul, 2016; Truglia, 2017). Despite considerable interest, these ventures face many barriers, among them limited capital, high operating costs, and challenges with environmental sustainability. One of our community partners suggests that there is greater potential in unheated greenhouses and other small-scale community ventures that are less costly to operate. For instance, the Kativik Regional Government is exploring the possibility of establishing local-scale egg, chicken, and rabbit production in Nunavik (Rogers, 2015).

Community organizations play a vital role in building capacity for local and regional food production. The Northern Farm Training Institute (NFTI) in Hay River, Northwest Territories, provides immersive farm training to northern residents, many of whom have gone on to start their own food businesses (NFTI, 2018). The Tr'ondëk Hwëch'in Teaching and Working Farm near Dawson City, a partnership between Tr'ondëk Hwëch'in and Yukon College, provides Indigenous youth with farming skills and produces a range of fresh vegetables, eggs, whole chickens, and pork products for the community and for sale. The long-term sustainability of these initiatives depends on widespread recognition of their valuable contributions to community food systems and sustained financial investment by governments and other partners.

\section{Fisheries}

Sustainable, Indigenous-managed commercial and small-scale fisheries offer a mechanism for increased traditional/country food production, food sovereignty and community economic development (FAO, 2012; Levkoe et al., 2017); however, there is limited research documenting the potential contributions of fisheries to food security 
in northern Canada. Historically, commercial fishing operations have primarily been commodity-focused and offered little value to surrounding Indigenous communities (FSC, 2011b; Ward, 2011; Ayles et al., 2016). In some cases, they promoted over-fishing of marine resources that are fundamental to subsistence harvests (Roux et al., 2011, 2019; Porta and Ayles, 2015; Ayles et al., 2016). Infrastructure is a major challenge for northern fisheries. Lack of existing ports, processing plants, and cold storage facilities prevent development of commercial fisheries (NIFI, 2018). Additionally, the high cost of production (energy, transportation, fuel, etc.) impedes potential profitability, an issue that requires concerted intervention to make northern commercial fisheries viable.

Opportunities for small-scale fisheries exist in both Nunavut and the Northwest Territories (Ayles, et al., 2016; NIFI, 2018; Roux et al., 2019); for example, Nunavut fishers are exploring the potential for small-scale, sustainable inshore commercial fisheries (SC, 2009).

The opportunities for developing small-scale, sustainable fisheries in the Arctic are likely to improve with climate change, where sustainable catch potential is calculated to be much higher than current levels (Tai et al., 2019). Small-scale fisheries offer the potential for regional economic development that simultaneously contributes to food security and sovereignty (SC, 2009; FAO, 2012). For such operations to be sustainable, however, it is essential that we improve our knowledge about commercial fisheries management and potential impacts on northern Canadian marine ecosystems (Ayles et al., 2016).

\section{Processing}

Beyond the primary harvest and production of food, there is a need to strengthen the capacity to store, transport, and transform foods. In northern contexts, processing includes slaughtering, butchering, freezing, canning, and drying foods, as well as producing prepared foods. Given the short seasons available for harvesting and agricultural production, processing is an essential means of adding value to harvested, fished, and farmed foods. Indeed, there is a long history of processing traditional/country foods at the family and community level involving the freezing, canning, smoking or drying of meat, fish, vegetables, and berries (FSN, 2009). Several recent programs have sought to strengthen and revitalize these practices, including the Country Food Processing Methods course in Inuvik (Inuvialuit Regional Corporation, 2016). At a commercial level, food safety regulatory frameworks and limited transportation networks also serve as barriers to marketing food across regional and territorial boundaries.

There are a number of innovative examples of regional, multi-species processing facilities that help to bring traditional/country foods to local and regional markets in a way that maintains important traditional cultural elements. For example, the Nunavut Development Corporation is majority owner of four of the five fish processing plants in Nunavut. Two of these, Kivalliq Arctic Foods and Kitikmeot Arctic Foods, are federally inspected facilities that also process caribou and muskox. Kivalliq's products include pipsi, a traditional/country food made from dried Arctic char; the company also offers a Country Food Pak that can be purchased and shipped across Nunavut. Research also indicates that mobile facilities have the potential to strengthen regional food systems, particularly in the North (Pinkney, 2014). The Yukon Governmentoperated mobile abattoir is a good example (GY, 2020). It provides red meat processing services for both domestic and wild animals (e.g., cattle, pigs, bison, elk, sheep, goats, and rabbits). While the unit can travel across the territory, a travel surcharge applies outside of Whitehorse, and the territorially inspected meat cannot be sold across territorial or provincial borders. The use and applicability of similar units is being tested in other parts of the North (e.g., Kenny et al., 2018b).

Infrastructure for food processing is needed to support larger-scale commercial activities, but also subsistence and small-scale food provisioning. For example, the Nunavut Fisheries Strategy highlights the need for port handling facilities, including community storage units and freezers (GN, 2016). Smaller-scale processing infrastructure is likewise needed to cut and wrap fish and meat, as well as dry and can other food products. Similarly, the Local Food Strategy for Yukon supports the development of community processing kitchens for harvesters, gardeners, and smallscale farmers (GY, 2016).

\section{Distribution}

The state of food distribution varies considerably across the North and is closely tied to limitations in transportation services. Some communities benefit from infrastructure associated with legacy or ongoing military, government or industrial investment, while others have limited capabilities beyond those that provide basic services. Yukon and Northwest Territories have modest road networks, while in Nunavut, Nunavik, and Nunatsiavut, transportation routes are exclusively by air and sea. Given the vast distances between settlements, air service has been described as "a lifeline" to northern communities (SC, 2013). Limited supply lines, vast distances, small populations, high operating costs, and the inelasticity of prices for fuel and other supplies combine to reduce the impact of competition in northern markets, resulting in high costs for air cargo services, especially in smaller communities. The recent merger of Canada's two largest northern airlines has compounded this situation (Murray, 2019). Notably, the extent to which air cargo can contribute to sustainable food systems is an important but complex question in this era of climate change associated with greenhouse gas emissions. A chief consideration in a life cycle analysis of greenhouse gas emissions for such products is whether or not these goods are sent on flights that are primarily intended for other purposes, such as those enabling people to travel 
between communities or to health care facilities (Saunders and Hayes, 2007).

While a limited number of marine sealift operators deliver bulk goods during the ice-off season, complex ordering and logistical requirements mean that few northern consumers can benefit from this pre-order method of purchasing shelf-stable items in bulk. Limited banking and consumer credit options are primary barriers for Northerners with fixed or seasonal incomes. Orders must be delivered to southern terminals well prior to sailing for cargo assembly and palletization. Weather and geography are also challenging; sealift arrivals vary annually, with service dates fluctuating by weeks or even months in different years. It is nearly impossible to plan with any accuracy for such variable resupply conditions. As a result, very few people have the wherewithal, equipment, and flexibility to effectively maintain their stores through this means.

\section{Retail}

The high cost of retail foods is commonly identified as one of the key determinants of food insecurity for northern Indigenous communities (CCA, 2014). High prices persist in northern communities despite federal food subsidies through Nutrition North Canada (NNC) (Galloway, 2017). The limited competition in the retail environment and the current food system inhibit new, smaller operations from establishing themselves (Burnett et al., 2015). The process for retailers to register with $\mathrm{NNC}$ can be time-consuming; one northern retailer experienced a 10 -month wait prior to becoming eligible for subsidy funds (Bell, 2017). Alternative models include Internet-based businesses, not-for-profit enterprises, and farmer's markets. However, these options are not yet widely available, and many communities continue to rely on a single retail outlet (Burnett et al., 2015).

Additional research is needed to examine nonmarket forms of food distribution, including traditional/ country food-sharing networks and emergency food access programs. Collings et al. (2016) examined the role of traditional/country food networks in mitigating food insecurity in Ulukhaktok, Northwest Territories, highlighting their role in increasing household access to nutritionally superior and culturally relevant food. We identified a number of food bank-type emergency food outlets in some northern communities (e.g., Kenny et al., 2018b); however, more information is needed to determine whether these initiatives meet community needs in ways that are both sustainable and culturally appropriate.

\section{OPPORTUNITIES FOR CHANGE: FEDERAL POLICY AND PROGRAM PRIORITIES}

A number of existing and proposed federal policy frameworks show promise for supporting the development of more sustainable northern food systems. In this paper, our focus is on those federal levers that would better support community-based initiatives working towards this end over both the short and long term. This work involves increasing the capacity to procure, process, and distribute a range of harvested, produced, and retail foods for sharing or sale. This transition toward more sustainable northern food systems also involves supporting community efforts to ensure more equitable access to healthy imported foods. Many of the current challenges involve barriers to engaging in particular food-provisioning activities or scaling-up food system activities or enterprises. Support is need to build capacity through training and knowledge transfer, while sustained funding is essential for enabling communities to implement identified solutions.

Following a food sovereignty approach, meeting these objectives demands made-in-the-North solutions that are attuned to particular cultural, geographic, environmental, and political contexts. At the federal level, the emphasis should be on relinquishing jurisdiction over food systems policy and programming to Indigenous organizations. This approach adheres to the federal government's commitment to negotiating new Crown-Indigenous relationships (PMO, 2015). Relinquishing federal sovereignty involves acknowledging the capacity of Indigenous communities to determine the future of their food systems and supporting the scaling-up of community innovations. Food-related programming already exists in most, if not all communities; however, it is generally ad hoc and inconsistently supported by both human and fiscal capital (e.g., Kenny et al., 2018b; Spring et al., 2018). There is a need to streamline the communication of priorities from the ground up in a way that informs policy and leads to tangible action. Former Chief of Vuntut Gwitchin and scholar Norma Kassi writes of the need to "build upon existing knowledge and resources ... we don't need to reinvent the wheel" (AICBR, 2017a).

Our research also reveals that solutions require integrated supply chains for both local and imported retail foods, as well as social economy and sharing networks for traditional/country foods and community-scale production. Solutions must be connected to broader economic and social development needs, including infrastructure, transportation networks, sufficient income levels, training and skills development, and cohesion and coherence within food policy or programs across departments and jurisdictions. As one engagement session participant based in Nunatsiavut noted:

\footnotetext{
Many of the northern regions still have huge inequity gaps when it comes to wealth, health, and quality of life. Until we build up the people of the North with adequate housing, access to health care, education and basic needs, it will be very difficult to create a thriving sustainable food system.
}

Overall, there is a need for connection and cohesion across government funding programs (both in terms of 
departments and jurisdictions). Food systems work is supported through various programs and funding streams. In addition to those explicitly geared towards food systems and food security, such as Agriculture and Agri-Food Canada (AAFC), there are a large number of northern economic development and capacity building programs that peripherally influence food system development. This overlap results in obscure and complex funding and policy arrangements for residents, organizations, and businesses to navigate. There is a need for greater regional staffing support for federal programs located in the North, including northern satellite offices for AAFC and the Canadian Food Inspection Agency.

There is no shortage of successful community-level and regional food systems initiatives that are working to respond to and address many of the challenges identified in this paper. One of the key tasks moving forward is to create a policy and program landscape that better supports these initiatives over the long term, without stifling the experimentation and social innovation that makes these place-based initiatives successful and effective. We discuss a number of pathways toward policy and program coherence below (see Table 1).

\section{Increase Harvest Capacity}

On-the-land programs provide skills training to young harvesters and support the transfer of traditional knowledge, with the aim of enhancing their capacity to bring food into the community over the long term. For example, the Traditional Food Program in Inuvik schools promulgates Inuit food-sharing values by creating opportunities for students to prepare and serve traditional/country foods to Elders at the city's long-term care centre (Kenny et al., 2018a). Community-based food sharing initiatives and the organizations that lead them highlight "the merits of placebased, experiential education for Indigenous youth and the need for appropriate policy to sustain these activities over the long term" (Kenny et al., 2018a:432).

Harvester Support Programs (HSP) (also known as Hunter Support Programs or Harvesters Assistance Programs) are an innovative blending of market and sharing economies, whereby the acquisition of harvesting equipment and tools is subsidized, or where wild meat and fish are purchased directly from harvesters for distribution to local community members. Gombay (2009:119) characterizes the Nunavik HSP as an "interesting mechanism through which Inuit have tried to accommodate their need for cash with their desire to preserve a variety of socio-economic institutions associated with their subsistence way of life." Established HSPs such as those currently operating in Nunavut and Nunavik provide communities with discretionary funding to support hunting and harvesting activities. Studies of HSPs point out that while such programming is vital to communities, the available funds are insufficient to cover all the required costs of harvesting and sharing traditional/ country foods (Chabot, 2003; Gombay, 2005; Hoover et al., 2016). Nevertheless, there is evidence that HSPs have positive economic impacts in communities. A 2003 study in Kuujjuarapik, Nunavik, reported that the $\$ 198000$ spent by the local HSP produced $\$ 482555$ worth of traditional/country foods, meaning that every dollar spent produced $\$ 2.50$ worth of available traditional/country food (Martin, 2003). HSPs differ in important ways from traditional/country food markets in that hunters are paid for their labour and costs, and food is shared with the community collectively.

Funding for HSPs typically derives from territorial or regional governments, however, the federal government recently announced additional funding for the Harvest Support Grant as part of its changes to the Nutrition North program (Crown-Indigenous Relations and Northern Affairs, 2018). It should be noted that some key informants caution that while HSPs maintain the cultural tradition of sharing traditional/country foods, they also alter the nature of sharing relationships, creating an institutionalized form of sharing rather than a network of reciprocal relationships within a community (Chabot, 2003; Martin, 2003; Gombay, 2009). There is also concern that HSP programs shift the economic dynamics of harvest, with hunters increasingly opting to be paid by the HSP rather than share their harvest directly with the community - starting a slippery slope towards greater commoditization of traditional/country foods.

Additional policy contributions to harvest activity come in two forms: wildlife management and traditional/ country food subsidy. Community engagement participants emphasized the need for greater recognition of community expertise in monitoring species populations, habitat, migration, and health - activities that support food system sustainability. Federal and provincial or territorial wildlife management could be enhanced by incorporating local harvesters' knowledge and observations, which would at the same time provide an additional source of revenue for communities struggling to maintain traditional knowledge and practices around environmental stewardship. With regards to the federal NNC food subsidy policy, for the subsidy to apply to traditional/country food, it must be processed in facilities that meet commercial, approved-forexport standards. Since very few such facilities exist in the North, traditional/country food accounts for less than $0.1 \%$ of annual subsidy expenditures (Galloway, 2017). There is strong pressure from Northerners to enhance federal supports that increase the availability and affordability of traditional/country foods (NNC, 2017).

It is important to recall that the production and sale of traditional/country foods are complex issues in the North. For many communities, selling food goes against cultural norms, and is prohibited by treaty and land-claim agreements. Other communities and regions across the North have different views on selling food and, as noted, are creating economic opportunities through food production. Traditional/country food is also sold though the informal economy, in which food is traded and shared through 
TABLE 1 . Summary of key goals and federal policy recommendations identified through our research and revised through the community engagement sessions.

\begin{tabular}{|c|c|}
\hline Goal & Policy recommendations \\
\hline \multirow{4}{*}{$\begin{array}{l}\text { Increase country food harvest capacity through } \\
\text { training and financial support }\end{array}$} & Support for on-the-land training opportunities and programs for northern youth. \\
\hline & Federal co-funding of Hunter Support Programs. \\
\hline & $\begin{array}{l}\text { Reinstate NNC subsidies for necessary non-food items such as harvesting, gathering, farming and } \\
\text { gardening equipment and increase support for programs enhancing access to country and community- } \\
\text { grown foods. }\end{array}$ \\
\hline & $\begin{array}{l}\text { Explore the establishment of country foods management or marketing boards to set regulations, } \\
\text { certification for country foods and engage in training and capacity building. }\end{array}$ \\
\hline \multirow[t]{3}{*}{ Increase local food production where viable } & $\begin{array}{l}\text { Establish a Northern Pillar or Stream within the Canadian Agricultural Partnership (CAP) or a } \\
\text { separate Northern Agriculture Development Initiative to provide funding and programs specific to } \\
\text { strengthening and supporting northern agriculture. }\end{array}$ \\
\hline & $\begin{array}{l}\text { Ensure CAP cost-share funding with territories is primarily directed towards diversity of producers and } \\
\text { organizations supporting local agriculture as eligible recipients. }\end{array}$ \\
\hline & $\begin{array}{l}\text { Eliminate the AgriDiversity Program's requirement of 50\% matching funds for not-for-profit } \\
\text { organizations. }\end{array}$ \\
\hline
\end{tabular}

Increase community and regional fisheries harvest, As part of the Northern Integrated Commercial Fisheries Initiative, prioritize small-scale Indigenous processing, and storage capacity commercial fisheries and increase regional processing capacity and strengthening domestic markets.

Increase regional food processing, inspection, storage, and value-added capacity

As part of the rural and northern priority area of the Investing in Canada Plan, provide funding to scaleup community and commercial level value-added processing and storage capabilities across the North.

Ensure funding and subsidy programs for northern food systems include processing for local and regional markets.

Increase the availability of Canadian Food Inspection Agency federal inspectors in the North.

Consider the establishment of a Wild Foods Inspection Act to develop specific food safety regulations to enable the sale and public institutional procurement of country foods.

Strengthen distribution networks within and across regions;

Strengthen transportation links within the North and between North and South

Ensure funding and subsidy programs for northern food systems include processing for local and regional markets (e.g., Nunavut Commercial Fisheries Freight Subsidy).

Establish a Northern Airports Capital Assistance Program to update northern infrastructure and improve remote airport services.

Co-fund freight subsidy programs at the territorial level for fisheries.

Increase the affordability of food and essential food-related items in retail stores;

Increase local food harvest and production

Regulate retail pricing for essential, subsidy-eligible items.

Reinstate subsidy eligibility for harvesting and agricultural equipment.

Increase funding for harvester support programs.

Incentivize retailers to purchase regionally produced and harvested foods.

communities to ensure access to this food resource for all. Therefore, conversations about traditional/country food production need to be had at both community and regional levels; one-size-fits-all approaches to food production policies will not meet the needs of northern communities.

\section{Increase Food Production}

Dedicated funding and policy priorities are essential to nurture burgeoning food production efforts in northern communities. Priorities include the development of northernbased production methods, separate eligibility thresholds to enable smaller operations to qualify for funding, and a stronger focus on direct economic development instead of research and public awareness initiatives.

Existing programs and funding supports for northern agriculture emerge from the Agricultural Policy Framework, a five-year agreement negotiated between the federal, provincial, and territorial governments. Certain programs are funded and managed by the federal government, with the remainder jointly funded by individual provinces and territories. The Canadian Agricultural Partnership (CAP) is a three billion-dollar agreement for 2018-23 that spans multiple sectors. Engagement session participants identified that the eligibility criteria and funding model for current CAP programs exclude smaller operations and community-scale food production initiatives. Concern was expressed regarding a draft description of the new CAP programs, wherein non-governmental organizations and Indigenous governments were not included as eligible recipients for all programs. In a letter submitted to Northwest Territories Minister of Industry, Tourism and Investment, a representative of the K'atl'odeeche First Nation (2018:1) wrote: "These guidelines appear to favour funding for [industry, tourism and investment] rather than for communities and, more specifically, work against First Nation interests in developing local agricultural initiatives." These sentiments were echoed by the submission of the NFTI (2018:2): "[t]he only way a truly sustainable agriculture sector will be developed in the NWT [Northwest Territories] is if all people, including Indigenous people, are supported and involved."

One new program of note within CAP is AgriDiversity. With a five million-dollar budget over the five years (2018-23), it is designed to encourage the participation of under-represented groups in agriculture, including women, 
youth, Indigenous peoples, and people with disabilities (AAFC, 2018b). AgriDiversity is only available to notfor-profit organizations, and applicants must contribute $50 \%$ to project costs. The requirement of matching funds, while common to many federal funding initiatives, poses a challenge for many smaller organizations and limits the participation of community-based organizations, many of which provide vital support to emerging northern agriculture ventures.

\section{Support Community-Controlled Commercial Fisheries}

Small-scale fisheries play an important role in local and regional food security. Efforts to shift towards more community-scale, Indigenous-controlled fisheries could have a meaningful impact on both economic development and community well-being. In 2017, the federal government announced the Northern Integrated Commercial Fisheries Initiative, a plan to extend federal supports for regional Indigenous fisheries to include regions previously ineligible for supports, notably Yukon, Northwest Territories, Nunavut, northern Quebec, and Newfoundland and Labrador (DFO, 2017b). Co-developed with the National Indigenous Fisheries Institute, the program offers a timely opportunity to prioritize small-scale Indigenous commercial fisheries, increase regional processing capacity, and strengthen domestic markets for sustainably harvested inshore species.

Support is needed to develop ports as well as processing and transportation infrastructure so that northern and Indigenous fishers can retain maximum value for their catch and strengthen regional distribution networks. A recent study commissioned by the Nunavut Department of Environment examined the feasibility of establishing an offloading facility for offshore vessels in Nunavut (GN, 2016). Such a facility would not only reduce operating costs for Nunavut fishing vessels, but also add \$1.1 million in wages to the regional economy. The community of Qikiqtarjuaq, Nunavut has been lobbying federal and territorial governments for a deepwater port for decades, as part of a strategy to increase much needed fish processing and transport infrastructure; however, it has yet to secure the needed investment (Qikiqtaaluk Corporation, 2015). In 2019 the National Indigenous Fisheries Institute conducted a review of Fisheries and Oceans programs that support Indigenous commercial fisheries to solidify the empirical basis for advocacy around this issue.

At the federal level, the Government of Canada recently concluded a review and consultation process on amendments to the Fisheries Act. Several of the announced changes will likely positively benefit northern and Indigenous fishers, including the requirement to consider the "adverse effects on the rights of Indigenous peoples of Canada when making decisions under the Fisheries Act" (GC, 2019), longer leases and licenses for harvesters and protection of small-holder and independent fishers (i.e., owner-operator policies and fleet separation policies), and the participation of Indigenous governing bodies in the development of future policy, project reviews, and monitoring (including the creation of an Indigenous Fisheries Advisory Council) (DFO, 2019; Laughren and Augustine, 2019). However, the language of consideration and participation falls short of guaranteeing respect for the rights of Indigenous peoples (Claxton, 2019). It will be important to ensure that full implementation and enforcement of proposed changes to the Fisheries Act aligns with court-affirmed recognition of the principles of Indigenous sovereignty and selfdetermination in all decisions relating to marine and fisheries management (King, 2011).

\section{Increase Regional Food Processing}

Territorial governments have made efforts in recent years to boost processing capacity within northern food systems. As part of Yukon's Local Food Strategy, the Yukon Government has committed to increasing the number of territorial meat inspectors to avoid delays at abattoir facilities (GY, 2016). The Government of Nunavut is actively promoting and seeking foreign investment in fish processing to boost economic development in the region (GN, 2018).

"Rural and Northern Communities Infrastructure" is one of five priorities of the federal government's Investing in Canada Plan (Infrastructure Canada, 2019). There is opportunity to collaborate with territorial governments to scale-up community- and commercial-level valueadded processing and storage capabilities. A recent federal funding partnership with the Northwest Territories included several themes related to food systems (GNWT, 2017), which hopefully indicates future investments in northern food systems infrastructure. Across federal programs, there is a need to ensure that funding and subsidy programs for northern food systems include processing and distribution that supports local and regional markets.

\section{Strengthen Regional Distribution Networks}

As noted earlier, the North lacks federally inspected animal product processing facilities; this lack hampers the ability of producers to sell their products across territorial boundaries. One reason is the limited availability of Canadian Food Inspection Agency inspectors in the North. Increasing northern inspection and accreditation capacity would be one way for the federal government to strengthen regional economies.

The selling and buying of traditional/country foods is a complex and nuanced issue, one that is beyond the scope of this paper. Discussion exists within the literature about the possibilities of establishing country food markets as a way of increasing the availability of traditional/ country food and providing financial compensation to hunters. However, these proposals are not without critique, particularly relating to the concern that traditional/country 
food markets may undermine traditional sharing networks that are fundamental to Indigenous culture (Chan et al., 2006; Damman et al., 2008; Gombay, 2009; Ford et al., 2016). These tensions were visible during the community engagement sessions, where some participants could see value in the commercialization of harvested foods, while others expressed concerns.

One proposal that merits further consideration is the establishment of a Wild Foods Inspection Act to develop specific food safety regulations that enable the sale of traditional/country foods within the North, particularly at public institutions such as schools and hospitals. Participants in a recent policy forum observed that "food safety regulations (which do not take into account an appropriate balance between food safety and traditional/ country food access) and practices (e.g. the unavailability of food inspection services in most northern communities) were considered to have a negative effect on access to traditional/country foods in communities" (Gordon Foundation, 2018:10-11). Similarly, one engagement session participant from Nunatsiavut noted that existing food safety regulations render it difficult to serve country food in health care facilities, schools, and seniors' homes. Food safety regulations were also highlighted as a barrier during the Yukon engagement session. Nunavut recently developed food safety guidelines for serving traditional/ country food in government-funded facilities and community programs (GN, 2017), which could serve as a model for similar regulatory programs across the North, while providing a source of revenue for harvesters. A related proposal involves the establishment of management and marketing boards to regulate the sale of traditional/ country foods and engage in training and capacity building. Models for these boards exist in the Certification and Market Access Program for Seals (DFO, 2017a) and the Genuine Mackenzie Valley Fur Program (Industry, Tourism and Investment, n.d.). Future discussions on the commercialization of traditional/country foods must be led by those communities that participate in the harvest of traditional/country foods and must be conducted in a way that allows different communities to have input on appropriate decisions for them and their particular context.

\section{Strengthen Transportation Networks}

Federal priorities in relation to northern transportation emphasize resource development rather than food systems. Recent editions of the Government of Canada's annual Transportation in Canada report contain not one reference to the challenge of transporting food to residents of northern communities. Reports spanning 2010-17 were examined for references to the search terms "north," "Arctic," "food," "resupply," and "Nutrition North Canada" (TC, 2019a). Federal investment, in partnership with territorial and regional governments, could bring much needed expansion and development of transportation networks within the North. In addition, federal support for programs that subsidize transportation costs between harvest locations and processing and retail and distribution locations, both within and beyond the North, would help to address a key bottleneck in scaling-up commercial harvest and agricultural activities. For example, Nunavut has a Commercial Fisheries Freight Subsidy to offset the high costs of shipping fish products for sale within Nunavut and to southern Canadian markets. Notably, this program excludes both transportation costs to ship fish to processing facilities within Nunavut and distribution costs within nonmarket contexts, such as for subsistence or communitylevel consumption.

The federal government has long provided investments in air transportation through its Airports Capital Assistance Program (TC, 2019b), although the program's limited budget means that capital upgrades to Canada's aging northern airport infrastructure fall far short of the backlog of identified needs (SC, 2013). However, given the vital role of air transportation for many northern communities, there have been calls for the creation of a similar northernfocused program to update and improve remote airport service in the North. This recommendation was echoed by the Canada Transportation Act Review Panel in 2015, but has yet to be implemented (TC, 2015).

\section{Increase Affordability of Retail Foods}

While Northerners indicate a strong preference for food sovereignty initiatives that reflect local and regional food harvest and production, food retail remains a prevalent feature of northern food systems. The federal Nutrition North Canada offers a market-driven subsidy that offsets retailer costs on a per-kilogram basis for perishable foods shipped to northern communities for retail sale (NNC, 2017). The program has been criticized for failing to reduce high food costs, failing to improve food quality, stifling retail competition in communities, limiting entrepreneurship, and exacerbating food insecurity in northern regions (Burnett et al., 2015; Galloway, 2017; Fafard-St. Germain et al., 2019). Subsidy critics have furthermore expressed concerns about community eligibility, rates of subsidization, food item eligibility, food quality, and northern retailer accountability (Auditor General of Canada, 2014; Galloway, 2017; Fafard-St. Germain et al, 2019). Our review concurs with these studies; we recommend that the federal government take immediate action to reduce retail food costs for people living in remote, northern communities through a combination of regulatory pricing and targeted subsidies. In addition, we suggest that the program reinstate subsidies for essential, non-food items such as harvesting, gathering, farming, and gardening equipment; increase support for programs that enhance access to regionally harvested and grown foods; and provide an incentive for retailers to purchase regionally-produced and harvested foods.

Beyond federal programs, subsidy models exist at territorial and provincial levels. Both Makivik Corporation 
and the Kativik Regional Government (the two main governing bodies in Nunavik) support a cost-of-living program (through an agreement with Transport Québec) that helps to defray the cost of essential household items (Rogers, 2019). Under this program, the cost of certain staple food items is reduced by as much as $20 \%$ (Duhaime and Caron, 2012). Complementary supports such as these offer promising avenues to support food security in retail environments.

\section{CONCLUSIONS}

The policy architecture that shapes northern food systems is characterized by overlapping governmental jurisdiction, meaning there is no simple or one-size-fitsall solution to the persistent challenge of northern food insecurity. However incremental progress toward northern sustainable food systems is being made across Canada through creative and concerted action across multiple sectors and scales.

The challenge of developing sustainable, northern food systems requires made-in-the-North solutions that are finely attuned to cultural, geographic, environmental, and political contexts. These solutions will result in policy interventions that are designed to support communityled initiatives rather than imposed, top-down or rigid frameworks to which communities must adhere. In particular, Indigenous self-determination and control over food system resources should be prioritized across policy and program domains, coupled with investments in capacity to ensure that community organizations and networks have the resources to carry out their work. Our engagement sessions highlighted the importance of providing sustainable funding to community organizations and support for the regional and national networks that bring these organizations together to share knowledge, successes, and lessons learned.

There is a need for polices to integrate and accommodate both market-based and subsistence supply chains, depending on local and regional contextual factors such as cultural acceptance of market mechanisms for food distribution. Further, policies should not assume that market-based mechanisms are inherently more desirable. Food provisioning within non-market sharing networks is crucial to long-term food security. This provisioning requires support for increased capacity-building around harvesting and production of traditional/country foods and the knowledge systems and relationships that make these activities possible. Coherence and the mainstreaming of food systems considerations across policies that impact northern communities are also essential. Food systems do not occur in a vacuum. Policy that enhances the linkages between food procurement and distribution with broader economic and social development is seen by many as the most effective approach. Crucial to the longevity of healthy northern food systems is support by all levels of government for community-level efforts to understand and mitigate against climate change, which affects all sectors.

Scholars and practitioners have identified the value of a joined-up food policy for Canada as a way to address the complex set of issues necessary for a sustainable food system (MacRae, 2011). After decades of research, advocacy, and consultation, in 2019, the federal government announced a food policy for Canada - a framework of programs and initiatives intended to steer our food systems in a more healthy, equitable, and sustainable direction (GC, 2019; Levkoe and Wilson, 2019). The result of advocacy from a range of food systems actors, the food policy represents an important first step in addressing several long-standing challenges in food systems across Canada and offers new policy support for northern food systems. It includes new programs with the potential to address some of the challenges identified in this paper, notable among them the Northern Isolated Community Initiatives Fund ( $\$ 15$ million over five years) that will "support community-led projects like greenhouses, community freezers, and skills training to strengthen Indigenous food systems, and combat significant challenges in accessing healthy food in Canada's North" (AAFC, 2019). A Local Food Instructure Fund (\$50 million over five years) and the creation of a Canadian Food Policy Advisory Council also have the potential to influence food systems policy at a more systemic level. Details of these funding initiatives have yet to be announced, but together with a new Crown-Indigenous partnership these initiatives move the federal position to a more decolonized approach to northern food policy.

Recent policy developments represent steps in the right direction, but continued work is needed. In particular, the federal government has an opportunity through the Food Policy for Canada to demonstrate its commitment to supporting sustainable and diversified food systems. It is essential that sustainable food systems advocates (e.g., academics, practitioners, and activists) continue to hold the government to account and take direction from northern and Indigenous communities in their efforts. Concerted action on the part of policymakers will eradicate the shameful spectre of hunger that continues to haunt northern communities in Canada and will support Northerners in their efforts to build sustainable, resilient food systems.

\section{ACKNOWLEDGEMENTS}

We would like to acknowledge Alison Blay-Palmer, Alex Boulet, Meghan Brockington, Rhonda Ferguson, Debbie Martin, Hugo Martorell, Michael Robidoux, and Soraya Sarshar who contributed to the research that informs this work. The following organizations provided administrative support or input into the analysis and policy recommendations: Food Secure Canada, Inuit Tapiriit Kanatami, the Inuit Food Security Working Group, the Arctic Institute of Community-Based Research, Ecology North, the Northern Farm Training Institute, and Econometric Research Limited. We would also like to acknowledge the support of 
Community First Impacts of Community Engagement (CFICE) in developing and conceptualizing this study as a communityacademic collaboration.

The original study was commissioned by Crown-Indigenous Relations and Northern Affairs Canada on behalf of the National Indigenous Economic Development Board (NIEDB). We are grateful for the input provided by members of NIEDB on a draft version of the policy recommendations, many of which informed their February 2019 publication Northern Sustainable Food Systems Recommendations Report. Finally, we would like to thank all the Northerners who participated in the research and shared their valuable insights and expertise drawn from their lived experience in building, strengthening, and re-imagining northern sustainable food systems.

\section{REFERENCES}

AAFC (Agriculture and Agri-Food Canada). 2018a. Canadian Agricultural Partnership: Building a strong agricultural and agri-food sector. News Release, February 13.

https://www.canada.ca/en/agriculture-agri-foodnews/ 2018/02/canadian_agriculturalpartnershipbuildingastrong agricultureandagr.html

—. 2018b. Canadian Agricultural Partnership: Federal activities and programs.

https://www.agr.gc.ca/eng/about-our-department/keydepartmental-initiatives/canadian-agricultural-partnership/ canadian-agricultural-partnership-federal-activities-andprograms/?id=1511361680577

- 2019. Food Policy for Canada.

https://www.canada.ca/en/agriculture-agri-food/ news/2019/06/food-policy-for-canada--backgrounder.html

AICBR (Arctic Institute of Community-Based Research). 2017a. Report on a food policy for Canada summit. Arctic Institute of Community-Based Research, 41094 Avenue, Suite 202, Whitehorse, Yukon Territory Y1A 1H6, Canada.

. 2017b. Healthy living inventory.

https://www.aicbr.ca/healthy-living-inventory

Andrachuk, M., and Smit, B. 2012. Community-based vulnerability assessment of Tuktoyaktuk, NWT, Canada to environmental and socio-economic changes. Regional Environmental Change 12(4):867-885.

https://doi.org/10.1007/s10113-012-0299-0

Auditor-General of Canada. 2014. Fall report of the AuditorGeneral of Canada. Chapter 6-Nutrition North CanadaAboriginal Affairs and Northern Development Canada. Ottawa, Ontario: Office of the Auditor-General of Canada. http://www.oag-bvg.gc.ca/internet/English/parl_oag_ 201411_06_e_39964.html

Avard, E. 2015 . Northern greenhouses: An alternative local food provisioning strategy for Nunavik. PhD thesis, Université Laval, Québec, Québec.

https://corpus.ulaval.ca/jspui/handle/20.500.11794/26517
Ayles, B., Porta, L., and Clarke, R.M. 2016. Development of an integrated fisheries co-management framework for new and emerging commercial fisheries in the Canadian Beaufort Sea. Marine Policy 72:246-254.

https://doi.org/10.1016/j.marpol.2016.04.032

Beaumier, M.C., and Ford, J.D. 2010. Food insecurity among Inuit women exacerbated by socioeconomic stresses and climate change. Canadian Journal of Public Health 101(3):196-201. https://doi.org/10.1007/BF03404373

Bell, J. 2017. Igloolik-based online upstart offers lower-cost food in Baffin. Nunatsiaq News, September 12.

http://nunatsiaq.com/stories/article/65674igloolik-based_ online_upstart_offers_lower-cost_food_in_baffin/

Brown-Paul, C. 2016. From snow to grow. Practical Hydroponics and Greenhouses 168.

https://search.informit.com.au/documentSummary;dn=112206 197142477; res=IELENG.

Burnett, K., Skinner, K., and LeBlanc, J. 2015. From food mail to nutrition north Canada: Reconsidering federal food subsidy programs for northern Ontario. Canadian Food Studies 2(1):141- 156 .

https://doi.org/10.15353/cfs-rcea.v2i1.62

Butler Walker, J., Kassi, N., Van Bibber, M., Friendship, K., Pratt, M., Alatini, M., Johnson, M.J., et al. 2017. Stories of Yukon food security. Northern Public Affairs 5(1).

http://www.northernpublicaffairs.ca/index/volume-5-issue-1/ stories-of-yukon-food-security/

CCA (Council of Canadian Academies). 2014. Aboriginal food security in northern Canada: An assessment of the state of knowledge. Ottawa, Ontario: Expert Panel on the State of Knowledge of Food Security in Northern Canada, CCA.

https:/cca-reports.ca/reports/aboriginal-food-security-innorthern-canada-an-assessment-of-the-state-of-knowledge/

Chabot, M. 2003. Economic changes, household strategies, and social relations in contemporary Nunavik Inuit. Polar Record 39(1):19-34. https://doi.org/10.1017/S0032247402002711

Chan, H.M., Fediuk, K., Hamilton, S., Rostas, L., Caughey, A., Kuhnlein, H., Egeland, G., and Loring, E. 2006. Food security in Nunavut, Canada: Barriers and recommendations. International Journal of Circumpolar Health 65(5):416-431. https://doi.org/10.3402/ijch.v65i5.18132

Chen, A., and Natcher, D. 2019. Greening Canada's Arctic food system: Local food procurement strategies for combating food insecurity. Canadian Food Studies 6(1):140-154.

https://doi.org/10.15353/cfs-rcea.v6i1.301

Kelly, J., Lanier, A., Santos, M., Healey, S., Louchini, R., Friborg, J., Young, K., and Ng, C. 2008. Cancer among the circumpolar Inuit, 1989-2003. II. Patterns and trends. International Journal of Circumpolar Health 67(5):408-420. https://doi.org/10.3402/ijch.v67i5.18349

Claxton, N.X. 2019. Reviewing the Fisheries Act: An Indigenous perspective. Toronto, Ontario: Yellowhead Institute, Ryerson University.

https://yellowheadinstitute.org/2019/03/25/reviewing-thefisheries-act/ 
Collings, P., Marten, M.G., Pearce, T., and Young, A.G. 2016. Country food sharing networks, household structure, and implications for understanding food insecurity in Arctic Canada. Ecology of Food and Nutrition 55(1):30-49.

https://doi.org/10.1080/03670244.2015.1072812

Crown-Indigenous Relations and Northern Affairs Canada. 2018. Immediate updates to the Nutrition North Canada and Harvesters Support Grant Programs. Ottawa, Ontario: Government of Canada.

https://www.canada.ca/en/crown-indigenous-relationsnorthern-affairs/news/2018/12/immediate-updates-tothe-nutrition-north-canada-and-harvesters-support-grantprograms.html

Cunsolo-Willox, A., Harper, S.L., Ford, J.D., Landman, K., Houle, K., Edge, V.L., and the Rigolet Inuit Community Government. 2012. "From this place and of this place": Climate change, sense of place, and health in Nunatsiavut, Canada. Social Science \& Medicine 75(3):538-547.

https://doi.org/10.1016/j.socscimed.2012.03.043

Dachner, N., and Tarasuk, V. 2016. Origins and consequences of and responses to food insecurity in Canada. In: Koc, M., Sumner, J., and Winson, A., eds. Critical perspectives in food studies, $2^{\text {nd }}$ ed. Toronto, Ontario: Oxford University Press. $221-236$.

Damman, S., Eide, W.B., and Kuhnlein, H.V. 2008. Indigenous peoples' nutrition transition in a right to food perspective. Food Policy 33(2):135-155.

https://doi.org/10.1016/j.foodpol.2007.08.002

Day, D.R., and Landolt, J.P. 1978. Feasibility study of an Arctic food producing facility. DCIEM Technical Report No. 78X2. Downsview, Ontario: Defence and Civil Institute of Environmental Medicine, Department of National Defence, Canada.

http://www.dtic.mil/dtic/tr/fulltext/u2/a055401.pdf

DFO (Fisheries and Oceans Canada). 2017a. Certification and Market Access Program for Seals (CMAPS). Ottawa, Ontario: DFO, Government of Canada.

https://www.dfo-mpo.gc.ca/fisheries-peches/seals-phoques/ certification-eng.html

2017b. News release: Co-development, co-design, and co-delivery of Indigenous fisheries programs. Ottawa, Ontario: DFO, Government of Canada.

https://www.canada.ca/en/fisheries-oceans/news/2017/10/codevelopment_co-designandco-deliveryofindigenousfisheriesp rogr0.html

- 2019. Introducing Canada's modernized Fisheries Act. Ottawa, Ontario: DFO, Government of Canada.

https://www.dfo-mpo.gc.ca/campaign-campagne/fisheries-actloi-sur-les-peches/introduction-eng.html

Donaldson, S.G., Van Oostdam, J., Tikhonov, C., Feeley, M., Armstrong, B., Ayotte, P., Boucher, O., et al. 2010. Environmental contaminants and human health in the Canadian Arctic. Science of the Total Environment 408(22):5165 - 5234. https://doi.org/10.1016/j.scitotenv.2010.04.059
Duhaime, G., and Caron, A. 2012. Nunavik comparative price index 2011. Chaire de Recherche du Canada sur la Condition Autochtone Comparée. Québec, Québec: Université Laval. http://www.chaireconditionautochtone.fss.ulaval.ca/ documents/pdf/ncpi-2011-eng-final.pdf

Egeland, G.M. 2010. Inuit health survey 2007-2008. Montréal, Québec: McGill University.

https://www.mcgill.ca/cine/files/cine/adult_report_nunavut. pdf

Egeland, G.M., Pacey, A.P., Cao, Z.C., and Sobol, I. 2010. Food insecurity among Inuit preschoolers: Nunavut Inuit Child Health Survey, 2007-2008. Canadian Medical Association Journal 182(3):243-248. https://doi: 10.1503/cmaj.091297

Egeland, G.M., Johnson-Down, L., Cao, Z.R., Sheikh, N., and Weiler, H. 2011. Food insecurity and nutrition transition combine to affect nutrient intakes in Canadian Arctic communities. Journal of Nutrition 141(9):1746-1753. https://doi:10.3945/jn.111.139006

Eneas, B. 2018. Caribou migration creates food security concerns. Laronge Now, March 6.

https://larongenow.com/2018/03/06/caribou-migrationcreates-food-security-concerns/

Environment Yukon. 2010. Status of Yukon fisheries 2010. Whitehorse: Yukon Department of Environment. https://yukon.ca/en/status-yukon-fisheries-2010

Ericksen, P.J. 2008. Conceptualizing food systems for global environmental change research. Global Environmental Change 18(1):234-245. https://doi.org/10.1016/j.gloenvcha.2007.09.002

Fafard-St. Germain, A.-A., Galloway, T., and Tarasuk, V. 2019. Food insecurity in Nunavut following the introduction of Nutrition North Canada. Canadian Medical Association Journal 191(20):E552-E558. https://doi.org/10.1503/cmaj.181617

FAO (Food and Agriculture Organization). 2012. Cooperatives in small-scale fisheries: Enabling successes through community empowerment. Rome, Italy: FAO. http://www.fao.org/docrep/016/ap408e/ap408e.pdf

Fondahl, G., and Irlbacher-Fox, S. 2009. Indigenous governance in the Arctic. A report for the Arctic Governance Project. Toronto, Ontario: The Walter and Duncan Gordon Foundation. https://arcticgovernance.custompublish.com/indigenousgovernance-in-the-arctic.4667323.html

Food Safety Network. 2009. Safe preparation and storage of Aboriginal traditional/country foods: A review. Vancouver, British Columbia: National Collaborating Centre for Environmental Health.

http://www.ncceh.ca/sites/default/files/Aboriginal_Foods Mar_2009.pdf

Ford, J.D., and Beaumier, M. 2011. Feeding the family during times of stress: Experience and determinants of food insecurity in an Inuit community. The Geographical Journal 177(1):44-61. https://doi: 10.1111/j.1475-4959.2010.00374 
Ford, J.D., Smit, B., and Wandel, J. 2006. Vulnerability to climate change in the Arctic: A case study from Arctic Bay, Canada. Global Environmental Change 16(2):145-160. https://doi.org/10.1016/j.gloenvcha.2005.11.007

Ford, J.D., Macdonald, J.P., Huet, C., Statham, S., and MacRury, A. 2016. Food policy in the Canadian North: Is there a role for country food markets? Social Science \& Medicine 152:35-40. https://doi.org/10.1016/j.socscimed.2016.01.034

FSC (Food Secure Canada). 2011a. Northern and remote local connections mapping project.

https://docs.google.com/spreadsheets/d/1otMtlnw 8 Gn6pdQTsuPxxI86J1_uuJBXlonEKtrFk8-U/edit?usp=sharing

2011b. Sustainable fisheries and livelihoods for fishers. Discussion Paper 5. Montreal, Québec: FSC.

https:/foodsecurecanada.org/sites/foodsecurecanada.org/ files/DP5_Sustainable_Fisheries_and_Livelihoods_for Fishers.pdf

Furgal, C., and Rochette, L. 2007. Qanuippitaa? How are we? Perception of contaminants, participation in hunting and fishing activities, and potential impacts of climate change. Québec: Institute National de Santé Publique, Quebec.

https://www.inspq.qc.ca/pdf/publications/691_esi_hunting_ fishing.pdf

Galloway, T. 2017. Canada's northern food subsidy Nutrition North Canada: A comprehensive program evaluation. International Journal of Circumpolar Health 76(1): 1279451.

https://doi: 10.1080/22423982.2017.1279451

GC (Government of Canada). 2019. Introducing a food policy for Canada. In: Budget 2019, Chapter 4: Delivering real change. Ottawa, Ontario: GC.

https://www.budget.gc.ca/2019/docs/plan/chap-04-en. html\#Introducing-a-Food-Policy-for-Canada

GN (Government of Nunavut). 2016. Nunavut fisheries strategy 2016 2020. Iqaluit: Fisheries and Sealing Division, Department of Environment.

https://assembly.nu.ca/sites/default/files/TD-277-4(3)EN-Department-of-Environment's-Nunavut-FisheriesStrategy,-2016-2020.pdf

2018. Fisheries and sealing programs. Iqaluit: Fisheries and Sealing Division, Department of Environment.

https:/gov.nu.ca/environment/information/fisheries-andsealing-programs

GNWT (Government of Northwest Territories). 2017. Northwest Territories agriculture strategy. The business of food: A food production plan 2017-2022. Yellowknife: Department of Industry, Tourism and Investment.

http://www.assembly.gov.nt.ca/sites/default/files/td_31418_282_29.pdf

Gombay, $\bar{N}$. 2005. The commoditization of country foods in Nunavik: A comparative assessment of its development, applications, and significance. Arctic 58(2):115-128. https://doi.org/10.14430/arctic405

. 2009. Sharing or commoditising? A discussion of some of the socio-economic implications of Nunavik's Hunter Support Program. Polar Record 45(2):119- 132.

https://doi.org/10.1017/S003224740800778X
Gordon Foundation. 2018. Recommendations on country/ traditional Food from the Northern Policy Hackathon. Toronto, Ontario: The Gordon Foundation.

http:/gordonfoundation.ca/app/uploads/2018/01/NorthernPolicy-Hackathon-Digital.pdf

Guyot, M., Dickson, C., Paci, C., Furgal, C., and Chan, H.M. 2006. Local observations of climate change and impacts on traditional food security in two northern Aboriginal communities. International Journal of Circumpolar Health 65(5):403-415.

https://doi.org/10.3402/ijch.v65i5.18135

GY (Government of Yukon). 2016. Local food strategy for Yukon: Encouraging the production and consumption of Yukon-grown food 2016-2021. Whitehorse: Agriculture Branch, Energy, Mines and Resources, GY.

https://yukon.ca/sites/yukon.ca/files/emr/emr-local-foodstrategy-for-yukon.pdf

2020. Book the mobile abattoir.

https://yukon.ca/en/book-mobile-abattoir

Hammond, K. 2017. The cost of healthy eating in Yukon, 2017. Whitehorse: Yukon Anti-Poverty Coalition.

https://yapc.ca/assets/files/Healthy Eating 2018.pdf

Hoover, C., Ostertag, S., Hornby, C., Parker, C., Hansen-Craik, K., Loseto, L., and Pearce. T. 2016. The continued importance of hunting for future Inuit food security. Solutions 7(4):40-50.

Huet, C., Rosol, R., and Egeland, G.M. 2012. The prevalence of food insecurity is high and the diet quality poor in Inuit communities. The Journal of Nutrition 142(3):541 -547.

https://doi.org/10.3945/jn.111.149278

Industry, Tourism and Investment. n.d. Genuine Mackenzie Valley Fur Program. Yellowknife: Government of Northwest Territories.

https://www.iti.gov.nt.ca/en/services/genuine-mackenzievalley-fur-program

Infrastructure Canada. 2019. Investing in Canada Plan. Ottawa, Ontario: Government of Canada.

https://www.infrastructure.gc.ca/plan/about-invest-aproposeng.html

Institute for Sustainable Food Systems. 2015. Yukon Food System Design and Planning Project: State of the Yukon food system 2011/2012. Richmond, British Columbia: Kwantlen Polytechnic University.

https://www.kpu.ca/sites/default/files/ISFS/YFSDPP-State of Yukon Food System_2015.01_1.pdf

Inuit Tapiriit Kanatami. 2020. Welcome to Nuluaq: The Inuit community-based food initiatives mapping project.

https://www.itk.ca/nuluaq-mapping-project/

Inuvialuit Regional Corporation. 2016. Country food processing methods course focuses on value-added techniques.

https://www.irc.inuvialuit.com/news/country-foodprocessing-methods-course-focuses-value-added-techniques

IPCC (Intergovernmental Panel on Climate Change). 2014. Climate change 2014: Synthesis report. Pachauri, R.K., and Meyer, L.A., eds. Contribution of Working Groups I, II and III to the Fifth Assessment Report of the Intergovernmental Panel on Climate Change. Geneva, Switzerland: IPCC. 151 p. 
Jorgensen, M. 2007. Rebuilding Native nations: Strategies for governance and development. Tucson: University of Arizona Press.

K'atl'odeeche First Nation. 2018. Letter to the Government of Canada concerning Canadian Agricultural Partnership (Unpubl.). PO Box 3060, Hay River, Northwest Territories X0E 1G4, Canada.

Kenny, T.-A., MacLean, J., Gale, P., Keats, S., Chan, H.M., and Wesche, S.D. 2018a. Linking health and the environment through education-A traditional food program in Inuvik, Western Canadian Arctic. Journal of Hunger \& Environmental Nutrition 13(3):429-432. https://doi.org/10.1080/19320248.2017.1420330

Kenny, T.-A., Wesche, S.D., Fillion, M., MacLean, J., and Chan, H.M. 2018b. Supporting Inuit food security: A synthesis of initiatives in the Inuvialuit Settlement Region, Northwest Territories. Canadian Food Studies 5(2):73-110.

https://doi.org/10.15353/cfs-rcea.v5i2.213

King, S.J. 2011. Conservation controversy: Sparrow, Marshall, and the Mi'kmaq of Esgenoôpetitj. International Indigenous Policy Journal 2(4): 5. https://doi.org/10.18584/iipj.2011.2.4.5

Kuhnlein, H.V., and Chan, H.M. 2000. Environment and contaminants in traditional food systems of northern Indigenous peoples. Annual Review of Nutrition 20:595-626. https://doi.org/10.1146/annurev.nutr.20.1.595

Kuhnlein, H.V., Receveur, O., Soueida, R., and Egeland, G.M. 2004. Arctic Indigenous peoples experience the nutrition transition with changing dietary patterns and obesity. The Journal of Nutrition 134(6):1447-1553. https://doi.org/10.1093/jn/134.6.1447

Lambden, J., Receveur, O., Marshall, J., and Kuhnlein, H.V. 2006. Traditional and market food access in Arctic Canada is affected by economic factors. International Journal of Circumpolar Health 65(4):331-340. https://doi:10.3402/ijch.v65i4.18117

Lambden, J., Receveur, O., and Kuhnlein, H.V. 2007. Traditional food attributes must be included in studies of food security in the Canadian Arctic. International Journal of Circumpolar Health 66(4):308-319. https://doi.org/10.3402/ijch.v66i4.18272

Laughren, R., and Augustine, R. 2019. New Fisheries Act could mark a turning point for Canada's depleted fisheries. The Hill Times, April 15.

Letcher, R.J., Bustnes, J.O., Dietz, R., Jenssen, B.M., Jørgensen, E.H., Sonne, C., Verreault, J., Vijayan, M.M., and Gabrielsen, G.W. 2010. Exposure and effects assessment of persistent organohalogen contaminants in Arctic wildlife and fish. Science of the Total Environment 408(15):2995-3043. https://doi.org/10.1016/j.scitotenv.2009.10.038

Levkoe, C.Z., Lowitt, K., and Nelson, C. 2017. "Fish as food": Exploring a food sovereignty approach to small-scale fisheries. Marine Policy 85:65-70. https://doi.org/10.1016/j.marpol.2017.08.018
Levkoe, C.Z., and Wilson, A. 2019. Policy engagement as prefiguration: Experiments in food policy governance through the National Food Policy Dialogue in Canada. In: Andrée, P., Clark, J.K., Levkoe, C.Z., and Lowitt, K., eds. Civil society and social movements in food system governance. Abingdon, United Kingdom: Routledge.

MacRae, R. 2011. A joined-up food policy for Canada. Journal of Hunger \& Environmental Nutrition 6(4):424-457.

https://doi.org/10.1080/19320248.2011.627297

Martin, D. 2012. The nutrition transition and the public health crisis: Aboriginal peoples on food and eating. In: Koc, M., Sumner, J., and Winson, A., eds. Critical perspectives in food studies, $1^{\text {st }}$ ed. Don Mills, Ontario: Oxford University Press. $208-222$.

Martin, T. 2003. De la banquise au congélateur: Mondialisation et culture au Nunavik. Sainte-Foy, Québec: Les Presses de l'Université Laval.

Murray, N. 2019. Federal government approves Canadian North and First Air merger. $C B C$ News, June 19.

https://www.cbc.ca/news/canada/north/canadian-north-firstair-merger-approved-1.5181975

Nancarrow, T.L., and Chan, H.M. 2010. Observations of environmental changes and potential dietary impacts in two communities in Nunavut, Canada. Rural and Remote Health 10(2): 1370 .

National Indigenous Economic Development Board. 2019. Recommendations on Northern Sustainable Food Systems. Gatineau, Québec: NIEDB.

http://www.naedb-cndea.com/reports/NORTHERN SUSTAINABLE_FOOD_SYSTEMS_RECOMMEND ATIONS\%20REPORT.pdf

NFTI (Northern Farm Training Institute). 2018. NFTI brief overview 2018. Hay River, Northwest Territories: NFTI. https://nftinwt.com/about/

Nickels, S., Furgal, C., Buell, M., and Moquin, H. 2006. Unikkaaqatigiit - Putting the human face on climate change: Perspectives from Inuit in Canada. Ottawa, Ontario: Inuit Tapiriit Kanatami.

NIFI (National Indigenous Fisheries Institute). 2018. Northern Integrated Commercial Fisheries Initiative: Discussion paper. Membertou, Nova Scotia: NIFI.

http://indigenousfisheries.ca/en/wp-content/uploads/2018/04/ The-Institute-Northern-Integrated-Commercial-FisheriesInitiative-Discussion-Paper-Sept-29.pdf

NNC (Nutrition North Canada). 2017. Nutrition North Canada Engagement 2016: Final report of what we heard. Ottawa, Ontario: NNC.

https://www.nutritionnorthcanada.gc.ca/eng/1491505202346/ 1491505247821

. 2018. Cost of the revised northern food basket in 2016-2017. Ottawa, Ontario: NNC.

https://www.nutritionnorthcanada.gc.ca/eng/1519997966920/ 1519998026166 
Nunavut Bureau of Statistics. 2018. Nunavut social assistance recipients by community, region and territory, 2009 to 2018. Rankin Inlet: Government of Nunavut.

https://www.gov.nu.ca/executive-and-intergovernmentalaffairs/information/social-data

Pakseresht, M., Lang, R., Rittmueller, S., Roache, C., Sheehy, T., Batal, M., Corriveau, A., and Sharma, S. 2014. Food expenditure patterns in the Canadian Arctic show cause for concern for obesity and chronic disease. International Journal of Behavioral Nutrition and Physical Activity 11: 51. https://doi.org/10.1186/1479-5868-11-51

Pal, S., Haman, F., and Robidoux, M.A. 2013. The costs of local food procurement in two northern Indigenous communities in Canada. Food and Foodways 21(2):132-152. https://doi.org/10.1080/07409710.2013.792193

Parlee, B.L., Sandlos, J., and Natcher, D.C. 2018. Undermining subsistence: Barren-ground caribou in a "tragedy of open access.” Science Advances 4(2): e170611. https://doi: 10.1126/sciadv.1701611

Pearce, T., Wright, H., Notaina, R., Kudlak, A., Smit, B., Ford, J., and Furgal, C. 2011. Transmission of environmental knowledge and land skills among Inuit men in Ulukhaktok, Northwest Territories, Canada. Human Ecology 39(3):271 - 288. https://doi.org/10.1007/s10745-011-9403-1

Pinkney, D. 2014. Mobile abattoirs in the context of Canadian local food system development: Niches and the potential for local food system resiliency. MSc thesis, University of Guelph, Guelph, Ontario.

PMO (Office of the Prime Minister of Canada). 2015. Minister of Crown-Indigenous Relations and Northern Affairs Mandate Letter. Ottawa: PMO.

https://pm.gc.ca/en/mandate-letters/minister-crownindigenous-relations-and-northern-affairs-mandate-letter

Porta, L., and Ayles, B. 2015. A history and context of commercial fishing in the Canadian Beaufort Sea-Amundsen Gulf. Report 2015-01. Inuvik, Northwest Territories: Canada/Inuvialuit Fisheries Joint Management Committee.

Power, E.M. 2008. Conceptualizing food security for Aboriginal people in Canada. Canadian Journal of Public Health 99(2):95-97.

https://doi.org/10.1007/BF03405452

Price, D.T., Alfaro, R.I., Brown, K.J., Flannigan, M.D., Fleming, R.A., Hogg, E.H., Girardin, M.P., et al. 2013. Anticipating the consequences of climate change for Canada's boreal forest ecosystems. Environmental Reviews 21(4):322-365. https://doi.org/10.1139/er-2013-0042

PROOF. 2018. Household food insecurity in Canada. PROOF: Food Insecurity Policy Research Fact Sheet. Toronto, Ontario: PROOF. https://proof.utoronto.ca/food-insecurity/

Qikiqtaaluk Corporation. 2015. Qikiqtarjuaq deep water port. https://www.qcorp.ca/en/project/qikiqtarjuaq-deep-water-port

Reyes, E.S., Liberda, E.N., and Tsuji, L.J.S. 2015. Human exposure to soil contaminants in subarctic Ontario, Canada. International Journal of Circumpolar Health 74(1): 27357. https://doi:10.3402/ijch.v74.27357
Robinson, S. 2010. Humble dreams: An historical perspective on Yukon agriculture since 1846. The Northern Review 32:135- 167 .

https://thenorthernreview.ca/index.php/nr/article/view/16

Rodon, T., and Schott, S. 2014. Towards a sustainable future for Nunavik. Polar Record 50(3):260-276. https://doi.org/10.1017/S003224741300013

Rogers, S. 2015. Local food production plan aims to feed Nunavik communities. Nunatsiaq News, May 26.

https://nunatsiaq.com/stories/article/65674food_production aims_to_feed_nunavik_communities/

2019. Quebec budget boosts cost-of-living subsidy for Nunavik. Nunatsiaq News, March 22.

https:/nunatsiaq.com/stories/article/quebec-budget-boostscost-of-living-subsidy-for-nunavik/

Rosol, R., Powell-Hellyer, S., and Chan, H.M. 2016. Impacts of decline harvest of country food on nutrient intake among Inuit in Arctic Canada: Impact of climate change and possible adaptation plan. International Journal of Circumpolar Health 75(1): 31127.

https://doi.org/10.3402/ijch.v75.31127

Roux, M.-J., Tallman, R.F., and Lewis, C.W. 2011. Small-scale Arctic char Salvelinus alpinus fisheries in Canada's Nunavut: Management challenges and options. Journal of Fish Biology 79(6): $1625-1647$. https://doi.org/10.1111/j.1095-8649.2011.03092.x

Roux, M.-J., Tallman, R.F., and Martin, Z.A. 2019. Small-scale fisheries in Canada's Arctic: Combining science and fishers' knowledge towards sustainable management. Marine Policy 101: $177-186$. https://doi.org/10.1016/j.marpol.2018.01.016

Saunders, C., and Hayes, P. 2007. Air freight transport of fresh fruit and vegetables. AERU Research Report No. 299. Christchurch, New Zealand: Agribusiness and Economics Research Unit, Lincoln University. https://core.ac.uk/download/pdf/35458650.pdf

SC (Senate of Canada). 2009a. Rising to the Arctic challenge: Report on the Canadian Coast Guard. Ottawa, Ontario: Standing Senate Committee on Fisheries and Oceans, Government of Canada.

https://sencanada.ca/content/sen/Committee/402/fish/rep/ rep02may09-e.pdf

- 2009b. Nunavut marine fisheries: Quotas and harbours. Ottawa, Ontario: Standing Senate Committee on Fisheries and Oceans, Government of Canada. http://assembly.nu.ca/library/Edocs/2009/001253-e.pdf

— 2013. One size doesn't fit all: The future growth and competitiveness of Canadian air travel. Ottawa, Ontario: Standing Senate Committee on Transport and Communications, Government of Canada. http://publications.gc.ca/site/eng/443211/publication.html . 2017. We can do it better: Housing in Inuit Nunangat. Ottawa, Ontario: Standing Senate Committee on Aboriginal Peoples, Government of Canada.

https://sencanada.ca/content/sen/committee/421/APPA/ Reports/Housing_e.pdf 
Sharma, S. 2010. Assessing diet and lifestyle in the Canadian Arctic Inuit and Inuvialuit to inform a nutrition and physical activity intervention programme. Journal of Human Nutrition and Dietetics 23(Suppl. 1):5-17. https://doi.org/10.1111/j.1365-277X.2010.01093.x

Shirley, S.M. 2016. Barriers to wildlife harvesting among Aboriginal communities in Canada and Alaska. MES thesis, School of Environment and Sustainability, University of Saskatchewan. https://harvest.usask.ca/handle/10388/7294

Slater, J., and Yeudall, F. 2015. Sustainable livelihoods for food and nutrition security in Canada: A conceptual framework for public health research, policy, and practice. Journal of Hunger \& Environmental Nutrition, 10(1):1-21. https://doi.org/10.1080/19320248.2015.1004220

Socha, T., Zahaf, M., Chambers, L., Abraham, R., and Fiddler, T. 2012. Food security in a northern First Nations community: An exploratory study on food availability and accessibility. International Journal of Indigenous Health 8(2):5-14.

Spring A., Carter, B., and Blay-Palmer, A. 2018. Climate change, community capitals, and food security: Building a more sustainable food system in a northern Canadian boreal community. Canadian Food Studies 5(2):111 - 141. https://doi.org/10.15353/cfs-rcea.v5i2.199

Statistics Canada. 2016. Farm and farm operator data, census of agriculture, Table 95-640-X. Ottawa, Ontario: Government of Canada. https://www.statcan.gc.ca/eng/ca2016

Tai, T.C., Steiner, N.S., Hoover, C., Cheung, W.W.L., and Sumaila, U.R. 2019. Evaluating present and future potential of Arctic fisheries in Canada. Marine Policy 108: 103637. https://doi.org/10.1016/j.marpol.2019.103637

Tansey, G., and Worsley, T. 1995. The food system: A guide. Sterling, Virginia: Earthscan.

TC (Transport Canada). 2015. Canada Transportation Act review - report. Ottawa, Ontario: Transportation Act Review Panel, Government of Canada.

https://www.tc.gc.ca/eng/ctareview2014/can a datransportation-act-review.html
. 2019a. Annual reports. Ottawa, Ontario: TC, Government of Canada.

https://www.tc.gc.ca/eng/policy/anre-menu.htm

— 2019b. Airports Capital Assistance Program. Ottawa, Ontario: TC, Government of Canada.

https://www.tc.gc.ca/en/programs-policies/programs/airportscapital-assistance-program.html

Truglia, E. 2017. Hydroponics for food security in the North. Montreal, Québec: McConnell Foundation.

https://mcconnellfoundation.ca/hydroponics-for-foodsecurity-in-the-north-3/

Veeraraghavan, G., Burnett, K., Skinner, K., Williams, P., Martin, D., Jamal, A., Ramsay, M., and Stothart, C. 2016. Paying for nutrition: A report on food costing in the North. Ottawa, Ontario: Food Secure Canada.

https://foodsecurecanada.org/paying-for-nutrition

Wakegijig, J., Osborne, G., Statham, S., and Issaluk, M.D. 2013. Collaborating toward improving food security in Nunavut. International Journal of Circumpolar Health 72(1): 21201. https://doi.org/10.3402/ijch.v72i0.21201

Ward, J. 2011. Fisheries development in Nunavut: The last frontier. The Journal of Ocean Technology 6(3):18-27.

WCED (World Commission on Environment and Development). 1987. Our common future. Oxford: Oxford University Press. https://sustainabledevelopment.un.org/content/documents/ 5987our-common-future.pdf

YAPC and AICBR (Yukon Anti-Poverty Coalition and Arctic Institute for Community-Based Research). 2017. What's your recipe for a better food system? Yukon Community Engagement - Report 2017. Whitehorse: YAPC and AICBR. https://static1.squarespace.com/static/56afc7218259 b53bd8383cb8/t/5a0b9368085229e38cf1b717/1510708075193/ Report-SubmissiontoAAFC-AFoodPolicy forCanada-Yukon Engagement-Recommendations+-noappendix3.pdf 